\title{
Research on the Curriculum Reform of "An Introduction to E-Commerce" Based on MOOC
}

\author{
Zhitan Feng ${ }^{\text {a }}$, Hui Shen \\ School of commercial, Nantong Institute of Technology, Nan Tong 226002, China \\ a Fengzhtan@126.com
}

\begin{abstract}
The Ministry of Education of China has established the establishment of high-quality "golden course" courses informatization and online and offline as an important construction direction for colleges and universities in the future. As an application-oriented undergraduate college, how to embody the application type, highlight the students' skill level, and use the online teaching platform such as the good motto class to create a golden lesson is also a question to be considered. The e-commerce major in the "Introduction to E-Commerce" course is electronic. The professional foundation course of business major is the first professional course for students to understand the profession and enter the profession. It has an important foundation and guiding role for the improvement of students' professional level and quality. This requires the establishment of the course to stimulate students' interest. Complete university studies. However, through the actual course teaching, we will find that this course has a single teaching mode in the teaching process, the course orientation is not accurate, the teaching methods, methods and contents are outdated, and the "double-teacher" type of teachers lacks such problems. In response to these problems, through the establishment of the online open platform platform, changing the teaching mode, updating the teaching content, strengthening the practical teaching, optimizing the teaching methods and methods, and actively introducing and cultivating the teachers' practical ability and level, and comprehensively improve the curriculum teaching. effect. In the teaching process of MOOC mode, there are many changes in the roles of teachers and students. Students should start from the pre-study class and enter the course. After each part of the course, they need to complete the exercises and discussions. The teachers need to strengthen the evaluation of the learning effects of each chapter of the course. And participation in professional counseling and discussion, these teachers put forward higher requirements in terms of professional competence and literacy. Both students and teachers need to constantly adapt to the requirements and changes of this model in order to meet the development needs of the new teaching model reform, and the curriculum will truly become a veritable "golden class."
\end{abstract}

Keywords: introduction to e-commerce; MOOC; online and offline teaching; curriculum reform.

\section{Introduction}

In 2012, the Ministry of Education issued the Notice of the Ten-Year Development Plan for Education Informatization (2011-2020) to promote education modernization with education informationization, integrate education informationization into the overall strategy of national informationization development, and accelerate the construction of educational information infrastructure. Advance the deployment of educational information networks to strengthen the development and application of quality educational resources. In 2014, the Ministry of Education, the Ministry of Finance, the National Development and Reform Commission, the Ministry of Industry and Information Technology, and the People's Bank of China issued a notice on the implementation of the "Implementation Plan for the Use of Informatization Means to Expand the Effective Mechanism of Quality Education Resources Coverage". It will expand the effective mechanism for the coverage of educational resources, realize the comprehensive and in-depth integration of information technology and education, improve the quality of education, and form an educational information system that is compatible with the development goals of national education modernization. On April 29, 2019, the Ministry of Education launched the "Six Excellence and Top-notch" Program 2.0. China's Minister of Education Chen Baosheng proposed to actively adapt to the needs of new technologies, new formats, new models, and new industries, and accelerate the layout of future strategic areas. The cultivation of talents is more diversified, more integrated, more clustered, 
more intelligent, and more international, and promotes and leads a new round of industrial transformation.

In the 2019 "Opinions on Deepening the Teaching Reform of Undergraduate Education and Improving the Quality of Talent Cultivation", the Ministry of Education put forward the goal of economic and social development and the goal of training talents, optimizing the proportion of public courses, professional basic courses and professional courses, and strengthening the overall design of the curriculum system. The curriculum construction is planned and systematic, avoiding randomization and fragmentation, and resolutely put an end to the class setting. Implement the "Double Thousand Plan" for the construction of first-class courses at the national and provincial levels, and strive to create a large number of offline, online and online offline, virtual simulation and social practice "Golden Lessons" with high-level, innovative and challenging degrees. . Actively develop "Internet + education", explore new forms of intelligent education, and promote the classroom teaching revolution. Strict classroom teaching management, strict adherence to teaching discipline, and ensure the quality of course teaching.

The Ministry of Education of China has established the high-quality "Golden Course" course of informationization and online and offline integration as an important construction direction for colleges and universities in the future. As an application-oriented undergraduate college, how to embody the application type, highlight the students' skill level, and use the online teaching platform such as the good motto class to create a golden lesson is also a question to be considered. The ecommerce major in the "Introduction to E-Commerce" course is electronic. The professional foundation course of business major is the first professional course for students to understand the profession and enter the profession. It has an important foundation and guiding role for the improvement of students' professional level and quality. This requires the establishment of the course to stimulate students' interest. Complete university studies.

\section{Teaching Status of the Course "An Introduction to E-Commerce"}

\subsection{Teaching Mode is Single}

In the course of the "Introduction to E-Commerce" course, the indoctrinating teaching method is still used. The teacher's lecture is the center, the lecture answering and answering is the main task, the systematic knowledge transfer, the knowledge transfer one-way, the critical thinking and the innovation Lack of consciousness, lack of meaning in school-enterprise cooperation, school-school cooperation and so on.

\subsection{The Course Orientation is not Accurate, the Course Content is Outdated}

In the course of teaching, the teaching points are mainly e-commerce transaction mode, online marketing, e-commerce payment and security, e-commerce website construction, etc., involving B2B, $\mathrm{B} 2 \mathrm{C}, \mathrm{C} 2 \mathrm{C}$ and other e-commerce platforms or models. Can not keep up with the development of ecommerce industry, e-commerce industry from the traditional model to social e-commerce, new retail, etc., has produced a lot of new theories, new concepts, change the entire e-commerce ecosystem, not updated in the teaching; The curriculum has not been organically integrated with enterprises and technology, and it does not attract students' interest in professional learning.

\section{3 “Double Teacher" Type Teacher Lacks}

The teaching content of the "Introduction to E-Commerce" course needs to be constantly updated, and needs to be closely linked with practice. These contents place high demands on teachers. As a teacher of this course, not only need to master the basic knowledge of e-commerce, but also need to pay attention to the development of e-commerce at any time, and require certain practical teaching ability. At present, the teachers in this course are mainly from the recent graduates of the school, lack of practical experience, and lack of high-level teachers such as doctors. The overall faculty is thin and the teaching team is not effectively established. 


\subsection{Course Lacks Practical Content}

This course is carried out in the first semester of the freshman year. There is no practical class during the first semester of the freshman year. There is no practical class. The arrangement of the teaching content lacks the practical ability of the students. The teaching process will affect the students' interest in learning. The understanding of professional knowledge is only understood literally and does not achieve the teaching effect. At the same time, the cooperation between schools and enterprises in e-commerce professional teaching is not deep, and the training base is insufficient, which affects the development of practical teaching content.

\section{Course Reform of "An Introduction to E-Commerce" based on MOOC}

In view of the problems in the teaching of the "Introduction to E-Commerce" course, according to the relevant requirements of the Ministry of Education and other departments, combined with the characteristics of the applied undergraduate school, explore the teaching ideas based on the MOOC, and complete the curriculum reform task through the online open curriculum construction.

\subsection{Establish a Student-Centered Teaching Model}

Change the teaching mode of the curriculum, from the teacher to the center to the student-centered, the teacher from the main body of the classroom to the leader of the teaching, the student as the main body. Focus on value shaping, ability development, knowledge transfer, and cultivating quality of personnel training. With the development of the information society, change the educational concept, establish a community of learning, subject, and effect, and make full use of information technology such as the Internet, cloud computing, and big data to establish a curriculum teaching system. The reform of classroom teaching mode is inseparable from information technology, and the development of information technology promotes the transformation of teaching mode. The construction of this course requires the use of information technology, the establishment of an online open course platform, and the completion of the course construction.

\subsection{Clarify the Course Positioning and Optimize the Teaching Content}

"Introduction to E-Commerce" is a professional basic course for e-commerce. The purpose of the course is to enable students to master the basic theoretical knowledge and skills of e-commerce, master the techniques and methods of e-commerce website planning and production, and master the development of e-commerce websites of different types of enterprises. The methods and strategies to understand the business model and profit model of different types of enterprise e-commerce websites, and to grasp the positioning of e-commerce websites of different enterprises. The e-commerce introduction course mainly includes understanding e-commerce, using e-commerce transaction mode (social e-commerce, rural e-commerce,cross-border e-commerce), e-commerce security management, e-commerce network marketing, electronic payment, mobile e-commerce, e-commerce logistics Management, website construction, and e-commerce laws and regulations, etc., introduce ecommerce front-end knowledge and content into the teaching content, and add the actual operation materials and videos of e-commerce platforms such as Jingdong, Tmall, and AliExpress to the teaching process. By strengthening the construction of informatization, we adopt a hybrid curriculum teaching model that combines online and offline to solve the problems of weak foundations and unclear goals for students. Through the construction of curriculum information, the main knowledge points will be digitized and videoized, and strengthened. The interaction of students, at the same time change the way of assessment of the curriculum, improve the proportion of process assessment and task assessment, and comprehensively examine the practical ability of students. The teaching content should reflect the latest developments and trends. From the design and integration of these teaching and practical content, it not only covers the development frontier of e-commerce industry, but also cultivates the quality of students' innovation and entrepreneurship. The introduction of practical content is in line with the cultivation of applied talents. 


\subsection{Changing Teaching Methods and Methods}

The teaching of this course is based on the platform of the MOOC. It adopts three steps: pre-study, in-class teaching and after-school review. The preliminary video viewing and practice are completed before the class, so that students can enter the classroom with questions; then classroom teaching, The theoretical and practical content of the course, using case teaching method, task teaching method, project teaching method to carry out teaching work, guide students to complete related tasks, exercise students' learning skills and level; after class, students are more difficult to understand according to the teacher's explanation in the classroom. The place to repeatedly watch the micro-course video and complete the after-school training, can also publish the discussion information through the discussion module; Finally, the teacher evaluates and summarizes according to the student's learning situation, discussion situation and classroom performance, on the one hand, evaluates the student's learning situation. On the other hand, according to the teaching situation and student response, the next stage of teaching methods and content will be changed.

At the same time, in the classroom teaching process, students are actively guided to participate in various types of e-commerce skills competitions, to promote learning in the competition, to promote the competition, to improve students' understanding of e-commerce, and to enhance students' interest in learning.

\subsection{Introduce "Double Teacher" Teachers and Self-cultivation to Create an Excellent Teaching Team}

In view of the lack of teachers in the e-commerce professional teaching process, especially the "double-skilled" teachers, the school introduces teachers from the e-commerce enterprises and other channels through various channels, and introduces foreign aid to improve the practical ability; on the other hand, Through the cooperation between schools and enterprises, the school policy guides, so that young teachers have the opportunity to enter e-commerce enterprises to engage in post-work practice, so as to enhance the professional operation level of teachers and the understanding and sensitivity of the e-commerce market. Therefore, we must pay equal attention to the introduction and training, and strive to build an excellent teaching team for e-commerce.

\section{Summary}

The teaching of the "Introduction to E-Commerce" course has a single teaching mode, the course orientation is inaccurate, the content is outdated, and the "double-teacher" type of teacher team lacks teaching methods and methods. In response to these problems, through the establishment of the online open platform, changing the teaching mode, updating the teaching content, strengthening the practical teaching, optimizing the teaching methods and methods, and actively introducing and cultivating the teachers' practical ability and level, and comprehensively improve the curriculum teaching. effect. In the teaching process of MOOC mode, there are many changes in the roles of teachers and students. Students should start from the pre-study class and enter the course. After each part of the course, they need to complete the exercises and discussions. The teachers need to strengthen the evaluation of the learning effects of each chapter of the course. And participation in professional counseling and discussion, these teachers put forward higher requirements in terms of professional competence and literacy. Both students and teachers need to constantly adapt to the requirements and changes of this model in order to meet the development needs of the new teaching model reform, and the curriculum will truly become a veritable "golden class."

\section{Acknowledgments}

Jiangsu Province Modern Educational Technology Research 2019 Annual Project "Practical Research on Application-based Undergraduate E-Commerce Teaching Mode under the Background of Modern Information Technology" (No. 2019-R-70610); First Level Key Built Discipline Projects 
of the Business Administration under Jiangsu Provincial "the 13th Five-Year Plan". Project number: SJY201609; Nantong Institute of Technology professor and doctoral research project (201823).

\section{References}

[1]. Zhang Jian. Research on the Reconstruction of E-commerce Course System Based on Project Teaching Method [J/OL]. Electronic World: 2-6[2019-10-20]. https:// doi.org/10.19353/ J. cnki. dzsj.20191015.001.

[2]. $\mathrm{Xu}$ Heming, Shi Jianyong. Discussion on the cultivation of e-commerce innovation and entrepreneurial talents in the era of big data [J]. E-commerce, 2019 (10): 70-71.

[3]. Zhang Zhizhen. Research on the Integration Mode of Innovation and Entrepreneurship Education and E-commerce Specialty[J]. China Management Informationization,2019(20):203-204.

[4]. Liu Yan. Research on Cross-border E-commerce Talents Training from the Perspective of Industry-University-Research Collaboration[J]. Journal of Jiamusi Vocational College, 2019(10): 293-294.

[5]. Sun Duan, Xiong Le, Yang Zihui. The Construction of E-Commerce Undergraduate Professional Characteristics Based on National Standards of Education Quality[J]. High Teaching Journal, 2019 (19):80-82.

[6]. Zhang Na, Huang Caizhen. Exploration of Practical Teaching System of Applied Undergraduate E-commerce Specialty[J].Journal of Shaoguan University,2019,40(08):72-75.

[7]. Shao Wei. Teaching Reform and Practice of the Applied Undergraduate Course "An Introduction to E-Commerce"[J]. Education Modernization, 2019, 6(52): 45-46.

[8]. Liu Huizhen. The Reform and Practice of E-commerce Course Based on "Double Creation" in Applied Undergraduate Colleges[J]. Journal of Jilin Engineering and Technology Teachers College, 2018, 34(12): 43-45.

[9]. He Xiaomin. On the Application of MOOC in Cross-border E-commerce Teaching[J]. Education and Occupation, 2018(12): 98-101.

[10]. Xue Ansong. Analysis of the teaching mode of "JAVA Programming" for applied undergraduate e-commerce majors [J]. Electronic Testing, 2017(24): 130-131. 